\title{
PATHWAYS OF ENTRY AND SPREAD OF RUST PATHOGENS: IMPLICATIONS FOR NEW ZEALAND'S BIOSECURITY
}

\author{
S.L.H. VILJANEN-ROLLINSON and M.G. CROMEY \\ New Zealand Institute for Crop \& Food Research Limited, Private Bag 4704, \\ Christchurch \\ Corresponding author: viljanens@crop.cri.nz
}

\begin{abstract}
The long distance dispersal of many plant pathogens has been well documented. This phenomenon is also common in Australasia, with wind currents and movement of people and possibly plant material facilitating introduction of several rust pathogens from Australia to New Zealand. The history of the arrival, survival and spread of three rust pathogens from Australia to New Zealand is outlined. Initial outbreaks of poplar rust in 1973, wheat stripe rust in 1980 and blackberry rust in 1990 are all likely to have been initiated from spores originating in Australia. After arrival, urediniospores have to be viable and there must be sufficient susceptible hosts and favourable environmental conditions so that initial infection foci can establish and facilitate further spread. This information is used to assess the risks posed to New Zealand by other rust pathogens that occur in Australia, such as asparagus rust, and to assess ways to minimise these risks.

Keywords: biosecurity, quarantine risk, rust, Puccinia.
\end{abstract}

\section{INTRODUCTION}

The rusts (Basidiomycetes: Uredinales), a diverse group of obligate biotrophic fungi, are among the most destructive of plant pathogens. They are of great economic importance throughout the world, causing devastating losses of many crops. For example, coffee rust destroyed all coffee in South Eastern Asia in the late 1800s. Yield losses due to frequent severe epidemics of rust diseases on cereals have been estimated at $10 \%$ of world production, but losses of up to $70 \%$ have been recorded on some crops (McIntosh et al. 1995). There are about 7000 described species of rust fungi worldwide; 234 of these are found in New Zealand with just over half being native species (McKenzie 1998). Most rust fungi are very specialised and attack only a single host family, genus or species. Rust fungi that are morphologically identical but attack different host genera are called formae speciales, within which there may be different pathotypes (also called races) that can attack only certain cultivars.

Rust fungi spread mostly by wind-blown spores although rain, animals, insects and humans may also play a role in dispersal. These pathogens are well known for their ability for long-range dispersal (Nagarajan \& Singh 1990; Agrios 1997). Two examples are the annual dispersal of Puccinia graminis Pers. f.sp. tritici, causing stem rust of wheat, from central Mexico to the Prairie Provinces of Canada, named the Puccinia Pathway (Kolmer 2001), and the likely dispersal of Hemileia vastatrix Berk. \& Br., the cause of coffee rust, from Angola to Brazil by wind currents (Bowden et al. 1971). This paper will outline three rusts, poplar rust, wheat stripe rust and blackberry rust, which appeared first in Australia and later in New Zealand. Implications for New Zealand's biosecurity are also outlined.

\section{INTRODUCTION OF A NEW RUST PATHOGEN}

Rust urediniospores are relatively thick-walled and resistant to degradation by UVlight, radiation, temperature and relative humidity. Consequently, urediniospores can survive outside a host for several days and hence can remain viable while transported 
over long distances (Agrios 1997). However, an epidemic will only occur if viable urediniospores are present at the relevant stage in the host life cycle, and present in sufficient quantities to initiate an epidemic before the hosts die or are harvested. There must also be sufficient susceptible hosts and favourable environmental conditions for germination, infection and subsequent development of the pathogen, and the pathogen must survive in the absence of host crops until the next growing season (Agrios 1997).

Close et al. (1978) reviewed the evidence for aerial transfer of plant pathogens, insects, seeds and pollen across the Tasman Sea from Australia to New Zealand. They estimated that there may be up to 30 days per year when suitable winds (those that come directly from the Australian coast and involve a passage time of 2 or 3 days) for appropriate trans-Tasman trajectories to occur. However, due to adverse route conditions, Close et al. (1978) claim that there would be only 21 evenly distributed occasions per year when a trans-Tasman crossing could take place in no more than 6 days. The spore descent is most likely to occur in the low-lying areas south of Auckland and in eddy effects near New Plymouth and north of Wellington. In the South Island the most likely areas for the spores to land are Tasman Bay, Otago and the West Coast. Wind-dispersed urediniospores of the pathogens causing rust diseases of Antirrhinum, Oxalis, poplar, wheat and blackberry are examples of rust pathogens that have achieved trans-Tasman dispersal (McKenzie 1998). In these cases, the pathogens have become established in the east coast of Australia (New South Wales or southern Queensland), before being found in New Zealand, often over a northern or western range. This reflects the flight path on the prevailing trans-Tasman westerly airflows (Wilkinson \& Spiers 1976; Close et al. 1978).

In addition to air dispersal, several rusts, especially of Northern Hemisphere origin, have been introduced by human activity, either accidentally or deliberately, into Australasia. The role of clothing and baggage of passengers arriving in New Zealand may be very important in the introduction of new pathogens. Sheridan (1989) collected a large number of fungal spores from inbound airline passengers and estimated that during the 4-week period of sampling at Wellington airport in 1982, 70000 viable rust urediniospores were brought in. Urediniospores of wheat stripe rust remain viable on clothing and are able to infect susceptible plants for at least 1 week (Wellings et al. 1987). Air passengers who have recently visited farms where they may have been exposed to plant pathogens pose the greatest risk, especially if they visit farms when in New Zealand. People engaged in outdoor pursuits may inadvertently bring pathogens adhering to outdoor equipment, such as tents, shoes and sports equipment.

Rust spores may also arrive in planting material, such as seeds, cuttings and bulbs, brought to the border as accompanied baggage, air or sea cargo, mail, vessels or personal effects (Williams et al. 2000). Rust spores may also arrive by adhering to material (e.g. soil or plant) on or inside containers and imported vehicles. However, quarantine measures currently in place should minimise the risk of introduction on such material. It is a serious concern that a great proportion of material arrives in New Zealand undeclared. Williams et al. (2000) found that about $34 \%$ of seed and nursery stock material seized at the border between January and March 1997 was undeclared.

\section{POPLAR RUST}

Poplars (family Salicaceae) are extensively used in New Zealand in shelterbelts and for erosion control, timber production, firewood, river control, amenity purposes and roughage for deer and goats. They are easy to propagate, and the extensive monoclonal plantings common in New Zealand are vulnerable to introduced pathogens. Prior to 1973, when two species of poplar rust were detected, New Zealand was free of growthlimiting diseases of poplars (Wilkinson \& Spiers 1976).

The American poplar leaf rust pathogen Melampsora medusae Thümen was first detected in Australia on 27 January 1972 on poplars near Sydney (Walker \& Hartigan 1972). Within 2 months this disease had spread over a large area from Melbourne to south Queensland. The European leaf rust pathogen Melampsora larici-populina Klebahn was found near Sydney 13 months later, and within 2 months had spread to most of New 


\section{Biosecurity}

South Wales. It is not as clear how these pathogens were introduced into Australia, but infected propagating material that had been illegally imported was the most likely avenue (Wilkinson \& Spiers 1976).

The rapid spread of $M$. medusae in Australia was noticed in New Zealand where McMillan (1972) warned of the risk of the rust arriving in New Zealand. Despite this, both rusts were found in New Zealand in 1973, when M. medusae was identified from trees in Kaikohe in Northland in March, and, at the same time, M larici-populina was identified from leaf samples originating from New Plymouth (van Kraayenoord et al. 1974). The introduction of these rusts to New Zealand most likely occurred via hightrajectory wind currents from Australia (Wilkinson \& Spiers 1976; Close et al. 1978). Wilkinson \& Spiers (1976) concluded that urediniospores of both species of rust were transported separately in large quantities from different regions of NSW. Melampsora medusae probably originated from north-eastern NSW where heavy infections were present in large plantations of poplar, and M. larici-populina probably originated from the Sydney area from heavily infected clones of poplar.

Within New Zealand, $M$. medusae initially spread through the northern half of the North Island. It was slow to develop after the initial occurrence, and the more aggressive spread of $M$. larici-populina meant that susceptible trees had already been defoliated by this pathogen. In addition, only a few clones of poplars susceptible to only M. medusae were grown in New Zealand, which severely restricted the spread of this pathogen. Apart from an occasional reintroduction via air currents from Australia, this species rarely occurs in New Zealand. The widespread occurrence of M. larici-populina is mainly due to the strong wind currents generally experienced within New Zealand, and successful overwintering on semi-evergreen Lombardy poplars widely planted in the North Island and Nelson. These provide large quantities of primary inoculum the following spring. Alternate hosts, such as larches, play an important role in providing inoculum throughout the year. Lombardy poplars are too susceptible to grow in the North Island. Since 1973 new resistant genetic material has been imported, and several resistant cultivars have been released (Spiers 1989). The planting of genetically diverse clonal mixtures has been advocated, but a further proof of the ever-changing nature of the pathogen is that the previously resistant cultivar Flevo is now also susceptible to the disease (Sheridan 2001).

\section{WHEAT STRIPE RUST}

Wheat stripe rust, caused by the pathogen Puccinia striiformis Westend. f. sp. tritici, was first recorded in Australia in 1979 (O'Brien et al. 1980). Plants infected with stripe rust pathotype 104E137A- were found in October 1979 in several locations in Victoria and New South Wales. It is thought that the pathogen was introduced to Australia by human activity as this pathotype was the prevalent one in Europe at the time, and it is unlikely to have arrived via wind currents. This same pathotype virulent on the host gene Yr2 was first recorded in New Zealand in November 1980 in Southland (Beresford 1982). The presumed mode of transport was from urediniospores on wind currents from eastern Australia. Some wheat cultivars in use at that time were very susceptible, and yield losses of up to $60 \%$ were reported (Beresford 1982). Once established in Southland, the pathogen spread rapidly northwards and by 1981 the disease was present in most susceptible wheat crops in both the South and North Islands.

In 1982, the previously resistant cultivar Oroua became heavily infected with stripe rust pathotype 106E139A-. This pathotype had virulence to the host gene $\operatorname{Yr} 7$ in addition to Yr2, and hence was postulated to have evolved from the original pathotype 104E137A-. In 1986, the pathotype 109E141A- (with virulence to the genes Yrl+YrO) was detected on the previously resistant cultivar Pegasus, which contains the resistance genes. Pathotype 109E141A- was common in Europe at the time and it is postulated to have been accidentally introduced on the clothing of a traveller a few weeks before its detection.

The number of stripe rust pathotypes continues to increase. This demonstrates the continuing increase in complexity of the rust in New Zealand. At least 33 pathotypes of 
P. striiformis have now been recorded in New Zealand, overcoming all but 3 of the more than 20 common resistance genes. Further pathotypes usually develop from single-gene mutations caused by high levels of UV-light in New Zealand, and occasionally exotic pathotypes arrive by other means. It is considered that at least four of the pathotypes are imports (three from Australia and one from Europe). Some of the pathotypes recorded in New Zealand do not exist in Australia, because of the different resistance genes contained in wheat cultivars commonly grown in Australia. A new pathotype will usually only become established in New Zealand if it is selected for by the use of cultivars with matching resistance genes. The more widely grown the cultivar, the more common the equivalent pathotypes will become. The climate in Canterbury, the major wheat growing area of New Zealand, is very conducive to the development of stripe rust which partly explains the large number of pathotypes that appear in this district. Two new pathotypes have been detected on barley grass and one on prairie grass, suggesting that barley grass may act as a source of new pathotypes, further threatening the effectiveness of known stripe rust resistance genes.

\section{BLACKBERRY RUST}

Blackberry rust (Phragmidium violaceum (Shultz) Winter) is the most recent example of a rust pathogen entering New Zealand from Australia. The European blackberry aggregate (Rubus fruticosus L. agg.) is a major weed of natural ecosystems in both Australia and New Zealand. While being investigated as a potential biological control agent (Bruzzese \& Hasan 1986), blackberry rust was found in southern Australia in February 1984 (Marks et al. 1984) presumably due to an illegal introduction. A more virulent strain F15 was released in Victoria in 1991 and 1992, and has been found to be more damaging to blackberry than the illegally introduced strain (Mahr \& Bruzzese 1998). The rust took almost 6 years to arrive in New Zealand where it was first found near Rakaia in Canterbury in January 1990 (Pennycook 1998). During the following 2 months, it was found at numerous other sites in Canterbury, Southland, eastern Otago, Chatham Islands and in one site in Taranaki in the North Island. Like wheat stripe rust, blackberry rust also spread northward, and since 1990 it has spread over most of the country. The original pathotype of the rust found in New Zealand was the same as that illegally released into Victoria in 1984. It is presumed that the rust arrived in New Zealand by airborne dispersal following a flight-path similar to wheat stripe rust since it was first found on the eastern side of the South Island, after presumably failing to establish on the West Coast of the South Island.

\section{LESSONS FROM PREVIOUS ENTRIES: MINIMISING THE RISK TO} NEW ZEALAND'S BIOSECURITY

There are several other rust pathogens not yet present in New Zealand, which pose a serious risk to the country's biosecurity. Of these, asparagus rust, caused by Puccinia asparagi DC. In Lam \& DC., poses the greatest risk because it is already present in Australia. It was first detected in south-east Queensland in March 2000 (Davis 2001a). Despite initial attempts at eradication, the rust had spread to a further 17 properties in the state by 2001, and is expected to spread to other states in the next few seasons (Davis 2001b). It is very likely that this pathogen will be carried to New Zealand, so it is important that appropriate steps are taken to ensure early detection leads to eradication if necessary. Contingency plans, such as epidemiological studies of the pathogen and identifying various control methods, must be put in place in case eradication will not be successful.

Other rust pathogens that have not yet been detected in Australia, but which pose a quarantine risk, are Physopella ampelopsidis (Dietel \& P. Syd.) Cummins \& Ramachar, causing grapevine leaf rust, and Puccinia psidii G. Wint. which causes rusts on a number of economically important tree crops, including Eucalyptus spp and other genera within the family Myrtaceae. Other economically devastating tree rusts, such as Cronartium, Endocronartium and Gymnosporangium, which are common in Europe and North 
America, would cause major economic losses were they to establish in New Zealand, especially to pine plantations.

The most likely methods of introduction of rusts to New Zealand are via wind currents or humans, either purposely or accidentally, as illustrated above. While entry via air currents is difficult to prevent, some practical steps can be taken to minimise the risk of other pathways of entry. High risk groups of air travellers, such as farmers, other agricultural workers, forestry owners and operators, travellers engaged in outdoor pursuits, plant breeders and pathologists, should be aware of the risks and take suitable steps to prevent the introduction of potentially damaging pathogens. These groups should take particular care when visiting crops, field sites and laboratories in other countries. Since one laundering of clothing may reduce the number of spores by only $50 \%$ (Sheridan \& Nendrick 1988), it would be advisable after return to New Zealand, to put items of clothing, shoes and watches in a plastic bag with a moistened towel or similar and leave overnight during which any viable spores would germinate (R. McIntosh, pers. comm.). Particular care should be used to decontaminate notebooks, as rust spores can adhere to them.

Planting material imported into New Zealand should go through official quarantine procedures which greatly minimises the risk of introducing new pathogens. Illegal importations of plant material probably poses the greatest risk to New Zealand's biosecurity. Public awareness should be increased as much as possible, together with detection (e.g. by x-ray) and interception of such material. Legal ways to import plant material should be affordable and readily available. Methods to prevent spread and establishment of plant pathogens once they have reached New Zealand are very difficult. For example, cordon sanitaire (a phytosanitary zone) of $50 \mathrm{~km}$ by $385 \mathrm{~km}$ was unsuccessful for preventing spread of coffee rust in South America in the early 1970s (Waller 1979) and attempts to eradicate asparagus rust in Australia seem to have failed (Davis 2001b). The earlier the detection, the more chance there is of successful eradication of unwanted organisms, so good crop surveillance is vitally important.

There is an urgent need to carry out risk and potential impact studies of exotic rust pathogens that could pose a problem to cultivated crops and indigenous plants in New Zealand. The protocol to asses the risk and impact of an exotic pathogen would follow well-defined steps, including gathering biological information on the pathogen; analysing this information and producing a model for pathogen-environment and disease-loss relationships; developing an integrated model and a geographic database including key variables for disease development and host growth; and finally, overlaying the disease prediction map on a host distribution map to provide a potential impact map (Yang et al. 1991). In addition, effects on value of crops/plants should be studied, together with cost-benefit analysis for eradication, control and for detection surveys. Rust pathogens may pose additional complications in these studies due to their highly adaptable nature making it difficult to predict in advance. Studies on impact scenarios for some rust pathogens, such as $P$. psidii, have already been started in New Zealand (Ridley et al. 2000) and overseas (Coutinho et al. 1998; Booth et al. 2002).

\section{CONCLUSIONS}

New Zealand has a vital interest in any new rust species that invade Australia as they are likely to be introduced into New Zealand. Research on risks of introduction, establishment and spread of exotic rust pathogens, and potential impact are urgently required. Illegal importation of plant material must be discouraged. Quarantine and interception services may need to be improved in Australasia. Finally, quarantine must remain affordable and user-friendly.

\section{ACKNOWLEDGEMENTS}

The New Zealand Foundation for Research, Science and Technology provided funding for this research. 


\section{REFERENCES}

Agrios, G.N. 1997: Plant Pathology. Academic Press, San Diego. 635 p.

Beresford, R.M. 1982: Stripe rust (Puccinia striiformis), a new disease of wheat in New Zealand. Cereal Rusts Bull. 10: 35-41.

Booth, T.H.; Old, K.M.; Jovanovic, T. 2000: A preliminary assessment of high risk areas for Puccinia psidii (Eucalyptus rust) in the Neotropics and Australia. Agric. Ecosyst. Environ. 82: 295-301.

Bowden, J.; Gregory, P.H.; Johnson, C.G. 1971: Possible wind transport of coffee leaf rust across the Atlantic Ocean. Nature 229: 500-501.

Bruzzese, E.; Hasan, S. 1986: The collection and selection in Europe of isolates of Phragmidium violaceum (Uredinales) pathogenic to species of European blackberry naturalized in Australia. Ann. Appl. Biol. 108: 527-533.

Close, R.C.; Moar, N.T.; Tomlinson, A.I.; Lowe, A.D. 1978: Aerial dispersal of biological material from Australia to New Zealand. Int. J. Biometeorol. 22: 1-19.

Coutinho, T.A.; Wingfield, M.J.; Alfenas, A.C.; Crous, P.W. 1998: Eucalyptus rust: a disease with the potential for serious international implications. Plant Disease 82: 819-825.

Davis, R.D. 2001a: Asparagus rust recorded in Australia. Australasian Plant Path. 30: 183-184.

Davis, R.D. 2001b: Three new fungal diseases of asparagus recorded in Queensland and their potential significance in Australia. Proc. Australasian Plant Path. Soc. Conf.: 104.

Kolmer, J.A. 2001: Early research on the genetic of Puccinia graminis and stem rust resistance in wheat in Canada and the United States. In: Peterson, P.D. ed. Stem rust of wheat, from ancient enemy to modern foe. APS Press, St. Paul, Minnesota. Pp. 51-82.

Mahr, F.A.; Bruzzese, E. 1998: The effect of Phragmidium violaceum (Shultz) Winter (Uredinales) on Rubus fruticosus L. agg. in south-eastern Victoria. Plant Prot. Quart. 13: 182-185.

Marks, G.C.; Pascoe, I.G.; Bruzzese, E. 1984: First record of Phragmidium violaceum on blackberry in Victoria. Australasian Plant Path. 13: 12-13.

McIntosh, R.A.; Wellings, C.R.; Park, R.F. 1995: Wheat Rusts: An Atlas of Resistance Genes. CSIRO, Australia. 200 p.

McKenzie, E.H.C. 1998: Rust fungi of New Zealand - an introduction, and list of recorded species. N.Z. J. Bot. 36: 233-271.

McMillan, R. 1972: Poplar leaf rust hazard. N.Z. J. Agric. 125: 47.

O'Brien, L.; Brown, J.S.; Young, R.M.; Pascoe, I. 1980: Occurrence and distribution of wheat stripe rust in Victoria and susceptibility of commercial wheat cultivars. Australasian Plant Path. 9: 14.

Nagarajan, S.; Singh, D.V. 1990: Long-distance dispersion of rust pathogens. Аnпu. Rev. Phytopath. 28:139-153.

Pennycook, S.R. 1998: Blackberry in New Zealand. Plant Prot. Q. 13: 163-174.

Ridley, G.S.; Bain, J.; Bulman, L.S.; Dick, M.A.; Kay, M.K. 2000: Threats to New Zealand's indigenous forests from exotic pathogens and pests. Sci. for Conserv.142: $1-68$.

Sheridan, J.E. 1989: Quarantine risks imposed by overseas passengers. N.Z. J. For. Sci. 19: 338-346.

Sheridan, J.E. 2001: First record in New Zealand of Melampsora larici-populina on Flevo poplar. Australasian Plant Path. 30: 177.

Sheridan, J.E.; Nendrick, D.H. 1988: II. Entry of plant pathogens into New Zealand. Botany Department, Victoria University of Wellington, Report No. 25.

Spiers, A.G. 1989: Introduction of poplar and willow pathogens into New Zealand and their effect. N.Z. J. For. Sci. 19: 347-352. 
van Kraayenoord, C.W.S.; Laundon, G.F.; Spiers, A.G. 1974: Poplar rusts invade New Zealand. Plant Dis. Rep. 58: 423-427.

Walker, J.; Hartigan, D. 1972: Poplar rust in Australia. Australasian Plant Path. Soc. Newsletter. 1:3.

Waller, J.M. 1979: The recent spread of coffee rust (Hemileia vastatrix Berk. \& Br.) and attempts to control it. In: Ebdels, D.L.; King, J.E. ed. Plant health, the scientific basis for administrative control of plant diseases and pests. Federation of British Plant Pathologists, Oxford. Pp. 276-283.

Wellings, C.R.; McIntosh, R.A.; Walker, J. 1987: Puccinia striiformis f.sp. tritici in Eastern Australia - possible means of entry and implications for plant quarantine. Plant Path. 36: 239-241.

Wilkinson, A.G.; Spiers, A.G. 1976: Introduction of the poplar rusts Melampsora laricipopulina and M. medusae to New Zealand and their subsequent distribution. N.Z. J. Sci. 19: 195-198.

Williams, P.A.; Nicol, E.; Newfield, M. 2000: Assessing the risk to indigenous New Zealand biota from new exotic plant taxa and genetic material. Sci. for Conserv. 143: 1-42.

Yang, X.B.; Dowler, W.M.; Royer, M.H. 1991: Assessing the risk and potential impact of an exotic plant disease. Plant Disease 75: 976-982. 